\title{
3D MODELING OF HISTORICAL DOGER CARAVANSARIES BY DIGITAL PHOTOGRAMMETRY
}

\author{
M.Yakar ${ }^{\text {a }}$, M.Uysal ${ }^{\text {b }}$, A.S.Toprak ${ }^{\text {c }}$, N.Polat ${ }^{\text {b }}$ \\ ${ }^{a}$ Selçuk Üniversitesi, Mühendislik-Mimarlık Fakültesi, Harita Mühendisliği Bölümü - \\ (yakar@selcuk.edu.tr) \\ b Afyon Kocatepe Üniversitesi, Mühendislik Fakültesi, Harita Mühendisliği Bölümü - \\ (muysal,npolat@aku.edu.tr) \\ ${ }^{c}$ Afyon Kocatepe Üniversitesi, Uzaktan Eğitim Meslek Yüksek Okulu, - (astoprak@aku.edu.tr)
}

KEY WORDS : Photogrammetry, 3D modelling, Caravansaries

\begin{abstract}
:
Caravansaries are sort of bigger khan that established on the busy trade roads to provide any kind of supplies but essentially all Caravansaries on Anatolia are established for caravans' accommodations which are passing through on caravan rout. After the Turks had chosen being Muslim, the land that Islam religion spread on it has expanded. As a result of this expansion it is required a safe route for trade caravans. During the ruling time of Seljuk's Empire, Caravansaries took the most advanced form. Sultans of the Seljuk's Empire were aware of importance of trade and economy. That's why they established Caravansaries near marines, between the important trade centers and on Anatolian lands which is a bridge between East and West. But these trade routes has changed at the time of Ottoman Empire. Many of the historical places in the world have been totally or partly destroyed by natural events and human activities such as earthquake, flood and fire until the present day and still going on. Documentation is essentially required for protection and restoration these historical places and photogrammetry is one of the most effective method for documentation of cultural heritages.
\end{abstract}

In this study, it is aimed to get 3D models of Doger Caravansaries which is established in Afyonkarahisar for relief and advertising. Doger Caravansaries was built in 15. Century at Sultan II Murat eras but the exact date of building is not known. The structure has rectangular plan in width. The total length of it is 56.50 in meters. The Caravansaries is consisting of attached two parts. The first part has two floors. There are pointed arched niches in the two sides of the wall and there are windows (iron barred) in the middle of the each niche. The door is fillet low arched. First floor rises on four elephant foot columns and ten other small columns. Short sides are covered by two each cross squinch and the other parts with barrel vault. There is a ladder with only ten remain levels opposite the main gate. Today, it has been cancelled to reach upstairs. The underside of the satires is empty. There are two loophole windows at the both two short side. The columns that are near the long walls are bounded each other with arches and overlaid with cross squinches. The rooms in the second floor have domes. One of these rooms was arranged as prey room. The second part of Caravansaries is single storey and walls made of rubble. There are four columns inside the room and they bounded with arches. Back side of the rooms were destroyed by earth quake and restored. This restoration was not appropriate with its original plan but the good one is that the Caravansaries was saved from totally comedown.

It is aimed to survey Doger Caravansaries Photogrammetricaly and generate 3D model covered by real tissues. In this study, South NTS-352 Total Station is used to constitute a closed polygon with 6 point. The coordinates of polygon points are calculated by distance and direction measurements. Levelling was carried out for determining the height of polygon points. Photographs was taken by Nikon D7000 camera. 3D model and faces were created in Photomodeler software.

\section{1. İNTRODUCTION:}

Historical artifacts are cultural legacies that hosting Many hundreds years of knowledge. This knowledge has to be transferred to the next generations. These historical heritages reflect the life style and aesthetic understanding of elder civilization as well as being cultural assets that hosting all changes in time such as wars and earthquakes.
The documentation and conservation of the natural tissues of historical monument without damaging is indispensable element for transferring future generations. It is a fact that cultural heritages not only in our country (Turkey) but also in many part of the world were damaged and being damaged. Because of this reason cultural heritages are partly documented in time all over the world. 
The work of documentation of historical places and cultural heritages is complex and multi-faceted process (Kulur, 2005). Documentation of historical or cultural structure covers the entire steps which is necessary for determining current state of the structure (shape and position) in three-dimensional space that are surveys, process, storage and presentation (Georgopoulos and Ioannidis, 2004). There are a few techniques for documentation of cultural heritages (Bohler and Heinz, 1999). These techniques which are very important and necessary, are traditional surveys, topographic techniques, photogrammetric surveys and scanning technique (Bohler and Heinz, 1999, Scherer, 2002).

At this point, it is a huge advantage that photogrammetry can provide reliable information in a short time (M. Yakar and H.M. Yllmaz, 2008). Nowadays, reconstruction of building in 3D model is very popular due to the developments in digital photogrammetry parallel to computer technology (Yakar et al., 2011). Today 3D building models become almost indispensable for city planning and tourism (Suveg and Vosselman, 2000).

In this study, it is aimed to reconstruction the Doger Caravansary that is in the city of Afyonkarahisar, in 3D model by the techniques of photogrammetry. In the field, 6 points are established as closed polygon which is covered the building. Coordinates of points are calculated in local system with surveying and levelling. Photographs are captured by using Nikon D7000 camera. 3D model is generated in Photomodeler software.

\section{FIELD WORKS}

In field work, local coordinate system is used for points. The mosque is covered with 6 points on the polygon. Not only Angles and distances are surveyed but also levels are determined with levelling. For the detail points of the Mosque, the facade photographs of the mosque are used. In the selection of detail points, the physical properties of the surface and sharp lines are considered. Same detail point on the mosque surface is surveyed from different polygon points as a control survey.

Photographs using for 3D model are captured with Nikon D7000 with a resolution of $16.1 \mathrm{MP}$ and $18 \mathrm{~mm}$ lens.it is paid attention for every photographs has at least 6 detail points on it. For every one of facades, the photographs are taken from different angles but photograph for the real surface covering are captured approximately perpendicular to the surface.

\section{OFFICE WORKS}

Office Works consist of coordinate calculations and generating 3D model. Basically all surveyed detail points data in the total station is transferred to computer. In Netcad software the 3D coordinates of point are calculated. İn the field work some surveys are made for controlling the detail points as same detail point is observed from different polygon points. At the result of this controls $4 \mathrm{~mm}$ differences are detected between both vertical surfaces and horizontal surfaces. At the end of all calculations and controls, the coordinates of points are saved in .txt format.

Interior orientation parameters of Nikon D7000 camera are get from PhotoModeler software and saved as .cam format. For absolute orientation the .txt and .cam files are used. After orientation processes we are ready for drawing. All facades are drawn from photographs which have different angles for same facade. Some details on the surface are defined from single photographs to surface. At the end of the drawing, 3D model is consisted. This model is covered with tissue automatically but some problems related covering are solved by selecting photographs manually. At the final stage, the orthophotos and facade drawns import to AutoCAD software to producing base plate.

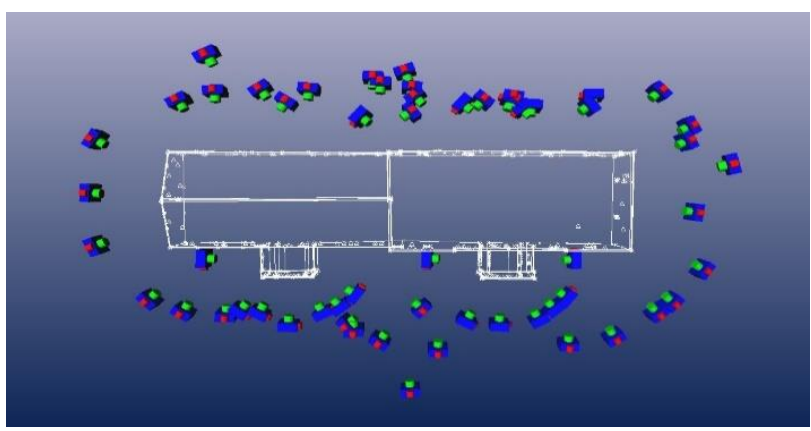

Figure 1. Camera points and control points for Caravansary

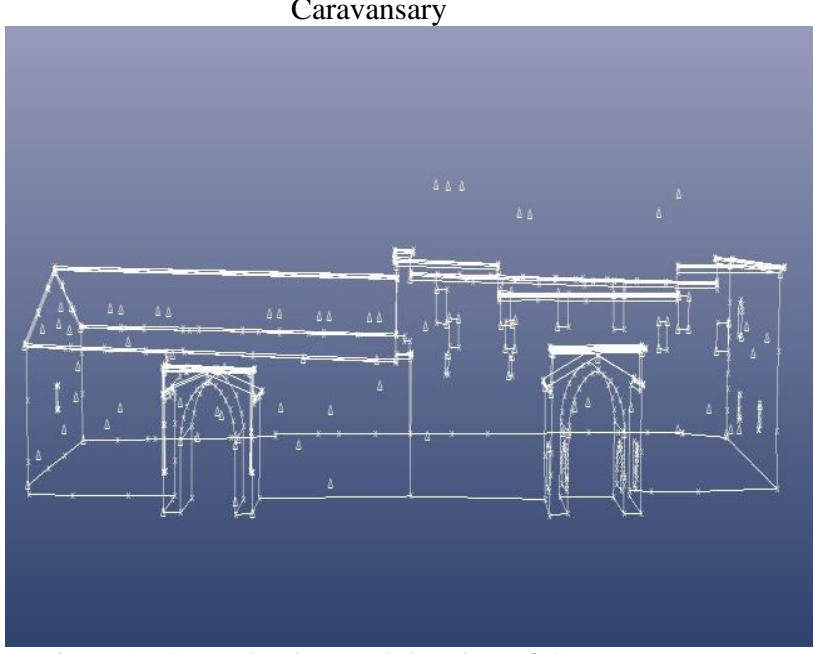

Figure 2. Control points and drawing of Caravansary

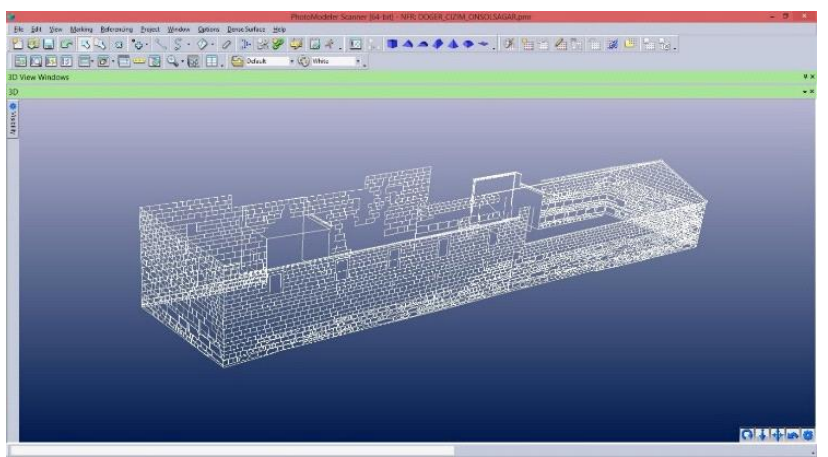

Figure 3. Drawing of Caravansary 


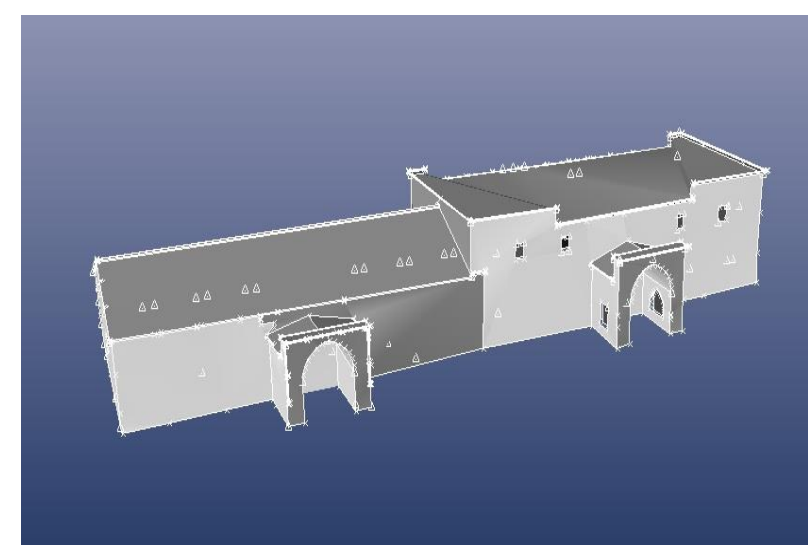

Figure 4. Control points and surfaces

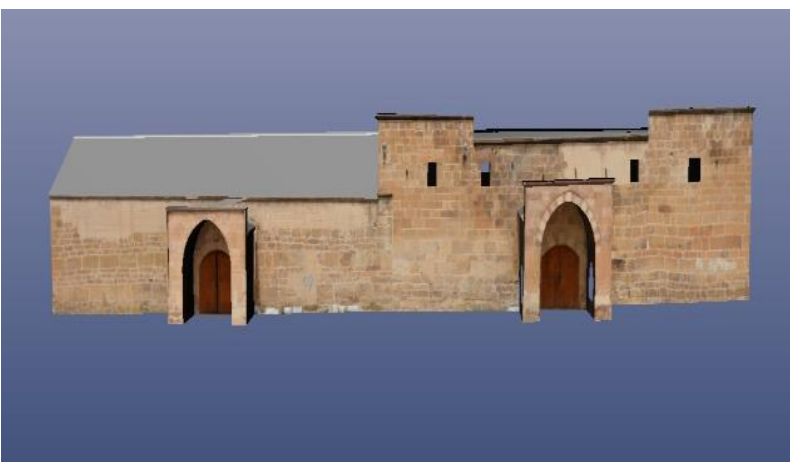

Figure 5. Covered surface frontline

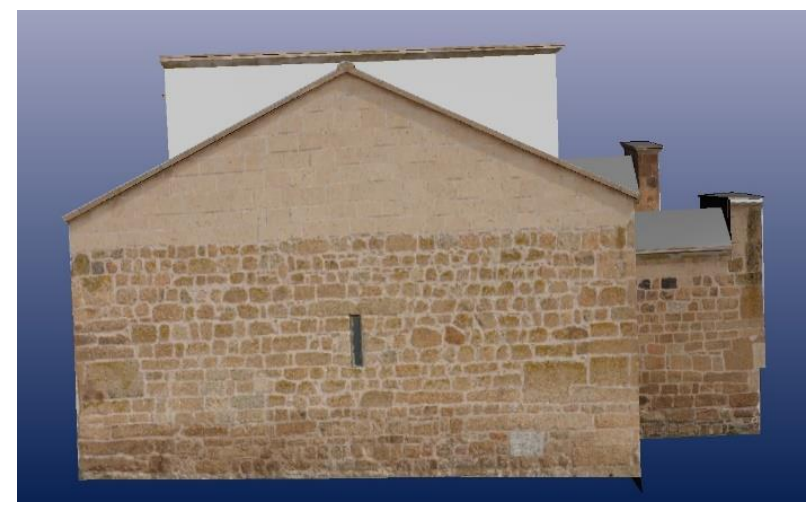

Figure 6. Covered surface sideline

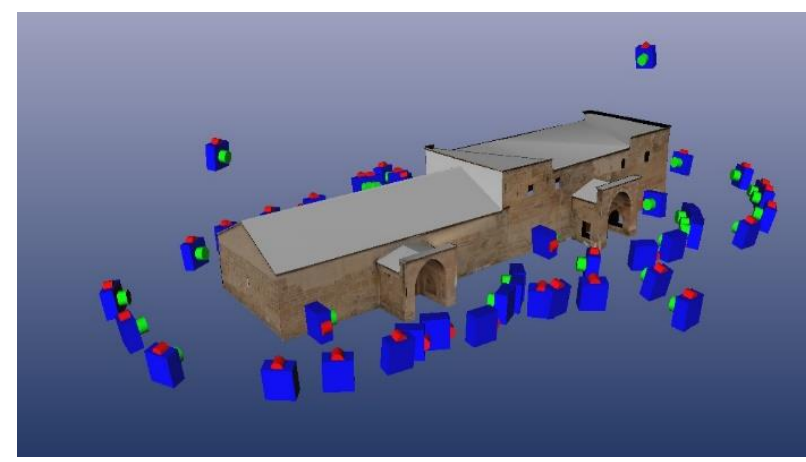

Figure 7. Camera points and Covered surface for Caravansary

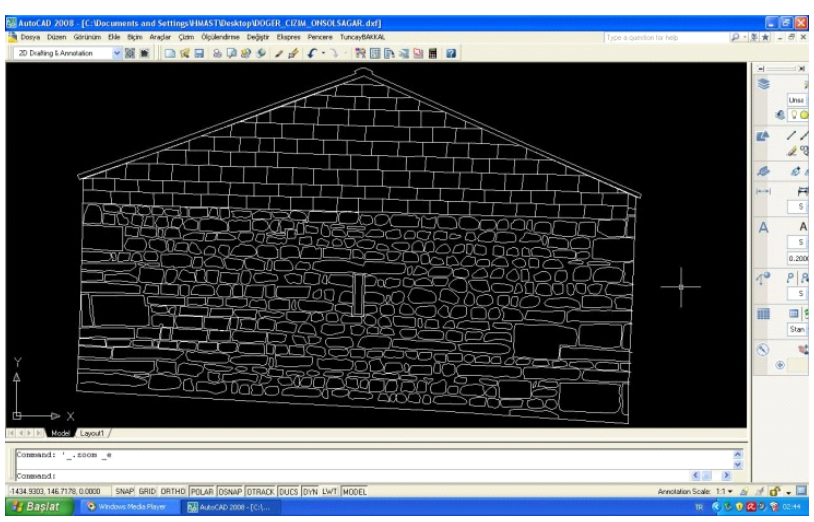

Figure 8. Surface of Caravansary in AutoCAD software

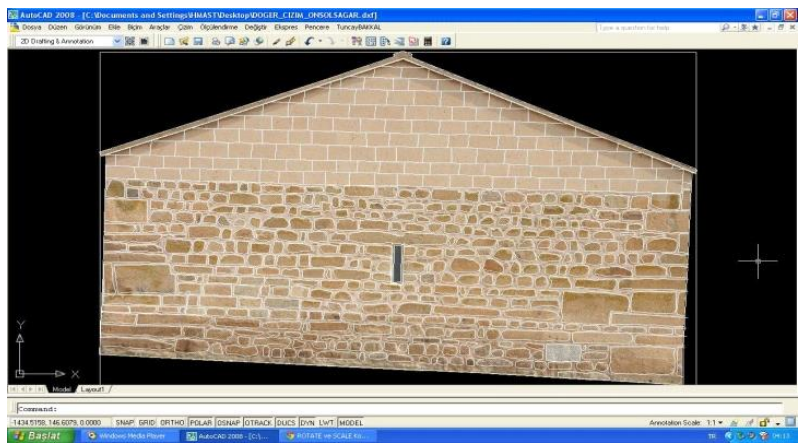

Figure 9. Orthophoto and drawing of surveys in AutoCAD software

\section{CONCLUSION}

The back side of Doger Caravansary is destroyed due to earthquake but it was not built again same as original. This shows how important and necessary is documentation of cultural heritages. It seen that for protection and transferrin of the cultural heritages and historical monuments to next generation, Terrestrial Photogrammetry has been brought a breath of fresh in terms of speed and cost. When it comes to cultural sites and objects, photogrammetry provides higher 3D models (building structures) accuracy at different scales (Remondino, 2011). It is observed that Threedimensional models produced by using photogrammetric techniques can be used for restoration projects as base plate and also this models can export VRML format to use in different applications (Carry and Bell, 1997). In this term it is obvious that the Photogrammetry can serve different disciplines with high accuracy.

\section{REFERENCESS}

Carey, R., Bell, G., 1997, "The Annotated VRML 2.0 Reference Manuel", Addison Wesley Developers Press

Georgopoulos A., Ioannidis G., 2004, Photogrammetric and urveying methods for the geometric recording of archaeological monuments, Archaeological Surveys, 
FIG Working Week 2004 Athens, Greece, May 2227,2004

Kulur S, Yilmazturk, F., 2005, 3D-reconstruction of small historical objects to exhibit in virtual museum by means of digital photogrammetry, CIPA 2005 XX. International Symposium, International Cooperation to Save the World`s Cultural Heritage, 26 Sep.-01 Oct. 2005, Torino, Italy.

Remondino, F., 2011, Heritage Recording and 3D Modeling with Photogrammetry and 3D Scanning. Remote Sens., 3, 1104-1138.

Scherer M., 2002, About the synthesis of different methods in surveying, XVIII International Symposium of CIPA, Potsdam, Germany.

Suveg, I., Vosselman, G., 2000, “3D Reconstruction of Buildings Models”, IAPRS, Vol. XXXIII, Amsterdam.

Yakar, M., Yılmaz H.M., 2008, Kültürel Miraslardan Tarihi Horozluhan'in Fotogrametrik Rolove Calısması ve 3 Boyutlu Modellenmesi, S.U. Muh.- Mim. Fak. Dergisi c.23, s.2, (in Turkish)

Yakar, M., Yıldız F., Özkütük, A., Neşeli, O., Kurhan, E., Durdu, O., 2011, Sultanhanı Kervansarayı Fotogrametrik Rölöve Alımı ve 3 Boyutlu Modelleme Çalışması, Tmmob Harita Kadastro Mühendisleri Odası, 13. Türkiye Harita Bilimsel ve Teknik Kurultayı, (in Turkish)

W. Böhler, G. Heinz, 1999, Documentation, surveying, photogrammetry, XVII CIPA Symposium. Recife, Olinda. 